\title{
Application Of Hybrid Learning Model In Foundation Engineering Subjects In Building Engineering Education Study Program, Palangka Raya University ACADEMIC YeAr 2020/2021
}

\section{Penerapan Model Pembelajaran Hybrid Learning Pada Mata Kuliah Teknik Fondasi Mahasiswa Prodi Pendidikan Teknik Bangunan Universitas Palangka Raya Tahun Akademik $2020 / 2021$}

\author{
Lola Cassiophea1), Ni Putu Diah Agustin Permanasuri2), Tubagus Prasatio $^{3)}$ \\ 1), 2) 3)Program Studi Pendidikan Teknik Bangunan FKIP, Universitas Palangka Raya \\ e-mail: Ilcassiophea@gmail.com
}

\begin{abstract}
There is now an assumption that "working from home" will become a normal work culture for most of us (teachers, and students). In Indonesia, some teachers have to do homework assignments (continuously and as a controlled routine) on an ongoing basis. This means that they have the opportunity to be unproductive to work in a completely new environment and without leadership supervision (intensively). However, there are a number of ways to get around this problem, especially preventing teachers from being confused in applying appropriate and effective learning models, as well as sustainable professional development, surely wanting to be productive in utilizing time during the Covid 19 pandemic. Thus time management must be carried out and controlled properly to improve the quality of professionalism of teachers as professional educators. The solution, the teaching staff is required to be able to design learning media as an innovation by utilizing online media. This research is motivated by the learning outcomes of Building Engineering Education students who program Foundation Engineering courses which are still relatively low under a score of 60 (C value). Hybrid learning is a hybrid learning concept that integrates traditional class sessions and e-learning elements in an effort to combine the benefits of the two forms of learning. The purpose of this study is to determine student learning outcomes after the application of the hybrid learning model. This type of research is descriptive research. Quantitative data in the form of numbers or scores obtained from student learning outcomes tests. This research was conducted from October 2020 to December 2020 at the Building Engineering Education FKIP, Palangka Raya University. The research subjects were students of the Building Engineering Education 2020/2021 Academic Year who program Foundation Engineering Courses. The instrument used in this study was the final test of student learning outcomes. There is a significant effect as evidenced by the analysis of the $t$-test with the results of $t$ count $>t$ table with a value of $t=22.4$ while for $t$ table $=2.04$ with a confidence of $0.05 \%$, there can be significant differences in learning using the hybrid learning model. . The output to be achieved is that this research will be published in the Journal of Technology and Vocational Education FKIP, Palangka Raya University, 'Balanga' not accredited in 2020.
\end{abstract}

Keywords: hybrid learning, foundation techniques, e-learning

\section{ABSTRAK}

Kini ada asumsi bahwa "bekerja dari rumah" akan menjadi sesuatu budaya kerja yang normal bagi kebanyakan dari kita (guru, dan siswa). Di Indonesia, beberapa guru harus mengerjakan tugas pembelajaran dari rumah (secara kontinyu dan sebagai rutinitas terkendali) secara berkelanjutan. Artinya, mereka berpeluang tidak produktif bekerja di lingkungan yang sama sekali baru dan tanpa pengawasan pimpinan (secara inten). Namun ada sejumlah cara menyiasati persoalan itu, terutama mencegah para guru kebingungan dalam menerapkan model pembelajaran yang tepat dan efektif, serta pengembangan profesi berkelanjutan, pasti ingin produktif dalam memanfaatkan waktu di masa pandemic Covid 19. Dengan demikian manajemen waktu harus dilakukan dan dikendalikan secara baik untuk meningkatkan kualitas profesionalitas guru sebagai pendidik professional. Solusinya, tenaga pengajar dituntut dapat mendesain media pembelajaran sebagai inovasi dengan memanfaatkan media daring (online). Penelitian ini dilatar belakangi oleh hasil belajar mahasiswa Pendidikan Teknik Bangunan yang memprogramkan Mata Kuliah Teknik Fondasi masih relatif rendah di bawah skor 60 (nilai C). Hybrid learning adalah konsep belajar hibrida yang mengintegrasikan sesi kelas tradisional dan elemen e-learning dalam upaya untuk menggabungkan manfaat dari kedua bentuk pembelajaran Tujuan penelitian ini adalah mengetahui hasil belajar mahasiswa setelah penerapan model pembelajaran hybrid learning. Jenis penelitian ini adalah penelitian deskriptif. Data kuantitatif berupa angka atau skor yang 
diperoleh dari tes hasil belajar mahasiswa. Penelitian ini dilaksanakan pada bulan Oktober 2020 sampai Desember 2020 di Pendidikan Teknik Bangunan FKIP Universitas Palangka Raya. Subjek penelitian yaitu mahasiswa Pendidikan Teknik Bangunan Tahun Ajaran 2020/2021 yang memprogramkan Mata Kuliah Teknik Fondasi. Instrumen yang digunakan dalam penelitian ini yaitu tes akhir hasil belajar mahasiswa. Terdapat pengaruh yang signifikan dibuktikan dengan analisi uji t-test dengan hasil $t_{\text {hitung }}>t_{\text {tabel }}$ dengan nilai thitung $=\mathbf{2 2 , 4}$ sedangkan untuk ttabel= 2,06 dengan kepercayaan $\mathbf{0 , 0 5 \%}$, maka dapat perbedaan yang signifikan pada pembelajaran yang menggunakan model pembelajaran hybrid learning. Luaran yang ingin dicapai adalah penelitian ini akan dipublikasikan pada Jurnal Pendidikan Teknologi dan Kejuruan FKIP Universitas Palangka Raya 'Balanga' tidak terakreditasi tahun 2020.

Kata Kunci : hybrid learning, teknik fondasi, e-learning

\section{PENDAHULUAN}

Sejak awal Maret 2020, istilah Work From Home (WFH) dan Study From Home (SFH) seakan menjadi topik utama di semua lini komunikasi di Indonesia. Hal ini terkait himbauan Presiden Republik Indonesia, Joko Widodo untuk melakukan social distancing atas penyebaran virus Corona (Covid19) yang oleh WHO sudah ditetapkan menjadi Pandemi. Sebelum Indonesia, di beberapa negara dengan tingkat kasus penyebaran virus corona yang lebih tinggi dan sudah lebih dulu menerapkan Work From Home (WFH) dalam aktivitas warganya (termasuk aktivitas bidang pendidikan). Pemerintah, Perusahaan, Lembaga pendidikan, serta masyarakat pun mulai menerapkan metode serta moda platform (program aplikasi) pendukung yang dapat membuat kegiatan Work From Home (WFH) dan Study From Home (SFH) menjadi efektif serta tetap menjaga produktivitas kerja maupun belajar.

Kini ada asumsi bahwa "bekerja dari rumah" akan menjadi sesuatu budaya kerja yang normal bagi kebanyakan dari kita (guru, dan siswa). Di Indonesia, beberapa guru harus mengerjakan tugas pembelajaran dari rumah (secara kontinyu dan sebagai rutinitas terkendali) secara berkelanjutan. Artinya, mereka berpeluang tidak produktif bekerja di lingkungan yang sama sekali baru dan tanpa pengawasan pimpinan (secara inten). Namun ada sejumlah cara menyiasati persoalan itu, terutama mencegah para guru kebingungan dalam menerapkan model pembelajaran yang tepat dan efektif, serta pengembangan profesi berkelanjutan, pasti ingin produktif dalam memanfaatkan waktu di masa pandemic Covid 19. Dengan demikian manajemen waktu harus dilakukan dan dikendalikan secara baik untuk meningkatkan kualitas profesionalitas guru sebagai pendidik professional.

Dalam proses pembelajaran mata kuliah Teknik Fondasi di Program Studi Pendidikan Teknik Bangunan Universitas Palangka Raya, pada masa pandemi covid 19 embelajaran dilakukan secara daring dan ditemukan beberapa permasalahan diantaranya mahasiswa mengatakan bahwa mata kuliah Teknik Fondasi sulit dipahami terutama konsep dasarnya. Mahasiswa cenderung hanya menguasai contoh soal yang diberikan, apabila diberikan sedikit variasi pada soal, mahasiswa tidak dapat mengerjakannya, karena kemampuan mereka sebatas kemampuan menghafal, sedangkan kemampuan untuk menguasai konsep dasar Teknik Fondasi masih sangat rendah.

Berdasarkan kenyataan tersebut, maka perlu dilakukan perbaikan dalam kegiatan pembelajaran dalam rangka meningkatkan kemampuan peserta didik untuk menganalisis dan mengerjakan soal yang bervariasi dari contoh yang diberikan pendidik untuk mencapai hasil belajar di atas skor lulus 60 (nilai C). Salah satu cara yang dapat digunakan adalah dengan penggunaan model pembelajaran yang lebih mengutamakan keaktifan mahasiswa dan memberi kesempatan mahasiswa untuk mengembangkan potensinya secara maksimal, dan model yang dimaksud yaitu model pembelajaran hybrid learning. Terminologi hybrid learning muncul setelah berkembangnya teknologi informasi sehingga sumber dapat diakses oleh mahasiswa secara offline maupun online.

Berdasarkan pernyataan di atas, maka perlu dilakukan perbaikan untuk meningkatkan keaktifan siswa dalam kegiatan pembelajaran. Salah satu model pembelajaran yang efektif pada saat pandemi covid 19 adalah dengan model hybrid learning yang merupakan campuran dari pembelajaran tatap muka dan pembelajaran online, sehingga memungkinkan pembelajaran tidak hanya terjadi di kelas saja namun juga dapat dilakukan di luar kelas.

Peneliti tertarik untuk melakukan penelitian terhadap mahasiswa Pendidikan Teknik Bangunan yang bertujuan untuk:

1) Membantu mahasiswa untuk lebih mudah dalam memahami, menganalisis dan mengerjakan soalsoal setiap materi pokok-pokok bahasan dalam mata kuliah Teknik Pondasi dan bersikap aktif saat kegiatan pembelajaran secara daring sehingga berpengaruh terhadap hasil belajar mahasiswa,

2) Dapat membantu mahasiswa yang mengalami kesulitan dalam mengerjakan soal-soal Teknik Pondasi untuk meningkatkan pemahaman mahasiswa.

3) Dengan dilaksanakannya penelitian ini, pendidik dalam hal ini dosen dapat mengetahui variasi strategi belajar mengajar yang dapat digunakan untuk meningkatkan hasil belajar peserta didik di Pendidikan Teknik Bangunan FKIP UPR selama masa pandemi Covid 19. 
Sedangkan manfaat penelitian ini adalah:

1) Bagi dosen, sebagai salah satu referensi model pembelajaran yang efektif di masa pandemi Covid 19 untuk meningkatkan hasil belajar mahasiswa

2) Bagi mahasiswa, memberikan fleksibilitas dalam memilih waktu dan tempat untuk mengakses pelajaran. Mahasiswa tidak perlu mengadakan perjalanan menuju tempat pelajaran disampaikan, e-learning bisa dilakukan dari mana saja baik yang memiliki akses ke internet ataupun tidak.

\section{TINJAUAN PUSTAKA}

Strategi Pembelajaran: Agar proses pembelajaran dapat terlaksana dengan baik diperlukan suatu strategi, hal ini dimaksudkan agar proses pembelajaran tidak keluar dari koridor-koridor yang telah direncanakan, agar tujuan pembelajaran dapat tercapai dengan baik dan optimal.

Hybrid learning merupakan istilah penyebutan untuk suatu strategi pembelajaranBlended/hybrid Learning yang mengalami penyempitan makna, dimana secara etimologiistilah Blended/hybrid Learning terdiri dari dua kata yaitu Blended/hybrid dan Learning. Kata blend berarti "campuran, bersama untuk meningkatkan kualitas agar bertambah baik" (Collins Dictionary), atau formula suatu penyelarasan kombinasi atau perpaduan (Oxford English Dictionary) (Heinze and Procter, 2006:236). Sedangkan learning memiliki makna umum yakni belajar, dengan demikian sepintas mengandung makna pola pembelajaran yang mengandung unsur pencampuran, atau penggabungan antara satu pola dengan pola yang lainnya.

Dari definisi tersebut dapat kita pahami bahwa hybrid learning merupakan penggabungan pembelajaran online dengan tatap muka di kelas. Pembelajaran secara tatap muka yang tradisional di kurangi akan tetapi tidak dihilangkan sama sekali. Penggabungan dari dua metode tersebut dimaksudkan untuk mengambil komponen komponen terbaik dari metode yang digabungkan tersebut. Hybrid learning di desain untuk mengintegrasikan aktifitas pembelajaran online dan tatap muka sehingga antara satu sama lainnya dapat saling menguatkan, melengkapi, dan mendukung serta tidak memperlakukan metode online sebagai duplikasi dari pembelajaran di kelas maupun sebagai tambahan saja (adds-on).

Dari definisi tersebut dijelaskan bahwa blended/hybrid leaming merupakan gabungan atau kombinasi dari dua atau lebih metode atau elemen untuk menyampaikan materi dalam pembelajaran. Terdapat 3 komponen dari blended/hybrid leaming yaitu online leaming, pembelajaran tatap muka atau konvensional, dan belajar mandiri. Online leaming dikombinasikan dengan pembelajaran tatap muka yang akan dibagi berdasarkan alikasi waktu yang telah disepakati. Dari definisi para ahli tersebut maka dapat disimpulkan bahwa blended/hybrid leaming adalah pengkombinasian atau pencampuran dua atau lebih komponen atau metode pembelajaran untuk mendapatkan hasil belajar yang diharapkan. Dari definisi para ahli tersebut juga maka sebagian besar komponen yang dicampur atau dikombinasikan dalam blended/hybrid learning adalah online leaming dengan pembelajaran tatap muka.

Tabel 1. Sintak Model Hybrid Learning

\begin{tabular}{|c|c|}
\hline Sintak & Peran Pengajar \\
\hline$(1)$ & $(2)$ \\
\hline $\begin{array}{l}\text { Fase: seeking of information } \\
\text { Pencarian informasi teknik pondasi dari } \\
\text { berbagai sumber informasi yang tersedia } \\
\text { di TIK (online), buku, maupun } \\
\text { penyampaian/ pendemonstrasian } \\
\text { fenomena empirik melalui face to face di } \\
\text { kelas }\end{array}$ & $\begin{array}{l}\text { - Dosen menyampaikan kompetensi dan tujuan } \\
\text { pembelajaran untuk menginisiasi kesiapan belajar } \\
\text { mahasiswa sekaligus mempersiapkan mahasiswa } \\
\text { dalam proses eksplorasi konsep teknik pondasi yang } \\
\text { relevan melalui kegiatan pembelajaran tatap muka } \\
\text { (face to face) di kelas maupun pembelajaran } \\
\text { dengan suplemen TIK(online). Kegiatan eksplorasi } \\
\text { konsep dapat dilakukan secara individual maupun } \\
\text { kelompok } \\
\text { Dosen memfasilitasi, membantu, dan mengawasi } \\
\text { mahasiswa dalam proses eksplorasi konsep teknik } \\
\text { pondasi, sehingga informasi yang diperoleh tetap } \\
\text { relevan dengan topik yang sedang dibahas, serta } \\
\text { diyakini validitas/reliabilitas dan akuntabilitas } \\
\text { akademiknya. }\end{array}$ \\
\hline $\begin{array}{l}\text { Fase: acquisition of information } \\
\text { Menginterprestasi dan mengelaborasi } \\
\text { informasi secara personal maupun }\end{array}$ & $\begin{array}{l}\text { - Dosen membimbing mahasiswa mengerjakan tugas } \\
\text { dalam diskusi kelompok untuk menginventarisasi } \\
\text { informasi, menginterpretasi dan mengelaborasi }\end{array}$ \\
\hline
\end{tabular}




\begin{tabular}{|c|c|}
\hline Sintak & Peran Pengajar \\
\hline$(1)$ & $(2)$ \\
\hline komunal & $\begin{array}{l}\text { konsep sains menuju pemahaman terhadap topik } \\
\text { teknik pondasi yang sedang dibelajarkan. } \\
\text { - Dosen mengkonfrontasi ide atau gagasan yang } \\
\text { telah ada dalam pikiran mahasiswa dengan hasil } \\
\text { interprestasi informasi/pengetahuan dari berbagai } \\
\text { sumber yang tersedia. } \\
\text { - Dosen mendorong dan memfasilitasi siswa untuk } \\
\text { mengkomunikasikan hasil interprestasi dan } \\
\text { elaborasi ide-ide sains secara tatap muka (face to } \\
\text { face) maupun menggunakan fasilitas TIK (online), } \\
\text { secara kelompok maupun personal. } \\
\text { Dosen men-scaffolding mahasiswa dalam } \\
\text { mengerjakan soal-soal teknik pondasi baik secara } \\
\text { personal maupun dalam kelompok } \\
\text { Dosen menugaskan siswa untuk mengelaborasi } \\
\text { penguasaan konsep teknik pondasi melalui } \\
\text { pemberian soal-soal teknik pondasi yang bersifat } \\
\text { terbuka dan kaya (open-rich problem). }\end{array}$ \\
\hline $\begin{array}{l}\text { Fase: synthesizing of knowledge } \\
\text { Merekonstruksi pengetahuan melalui } \\
\text { proses asimilasi dan akomodasi bertolak } \\
\text { dari hasil analisis, diskusi dan perumusan } \\
\text { kesimpulan dari informasi yang diperoleh }\end{array}$ & $\begin{array}{l}\text { - Dosen menjustifikasi hasil eksplorasi dan akuisasi } \\
\text { konsep sains secara akademik, dan bersama-sama } \\
\text { mahasiswa menyimpulkan konsep teknik pondasi } \\
\text { yang dibelajarkan. } \\
\text { - Dosen membantu mahasiswa mensintesis } \\
\text { pengetahuan dalam struktur kognitifnya } \\
\text { - Dosen mendampingi mahasiswa dalam } \\
\text { mengkonstruksi/merekonstruksi konsep teknik } \\
\text { pondasi melalui proses akomodasi dan asimilasi } \\
\text { bertolak dari hasil analisis, diskusi dan perumusan } \\
\text { kesimpulan terhadap informasi sains yang } \\
\text { dibelajarkan }\end{array}$ \\
\hline
\end{tabular}

(Diadaptasi dari Grant,2001)

Hasil belajar merupakan perolehan dari proses belajar mahasiswa sesuai dengan tujuan pengajaran. Hasil belajar menunjukkan prestasi belajar dengan memahami dua kata yang membentuknya, yaitu "hasil" dan "belajar". Belajar adalah suatu tahapan aktivitas yang menghasilkan perubahan perilaku yang bersifat relatif tetap sebagai bentuk respons terhadap suatu situasi atau sebagai hasil pengalaman dan interaksi dengan lingkungan.

Hasil adalah menunjukkan pada perolehan akibat dilakukanya suatu aktifitas atau proses yang mengakibatkan berubahnya input secara fungsional. Saat ini kita telah memasuki suatu era dimana perpaduan antara dunia maya dan dunia nyata teijadi semakin erat, hal ini banyak didengung-dengungkan oleh para pakar sebagai era konvergensi. Era konvergensi telah mempengaruhi berbagai aspek dalam kehidupan manusia, pendidikan merupakan salah satu aspek yang ikut terpengaruh oleh perkembangan tersebut. Para ahli pendidikan kemudian mencari berbagai solusi dalam rangka menghadapi perkembangan teknologi serta perubahan paradigma masyarakat yang semakin pesat, salah satu solusi yang ditawarkan adalah dengan di temukannya suatu model pembelajaran online (online learning). Pembelajaran online merupakan model pembelajaran yang dimaksudkan untuk membuat suatu proses pembelajaran menjadi lebih terbuka dan fleksibel tanpa dibatasi ruang dan waktu, sehingga si belajar dapat melakukan suatu proses pembelajaran kapanpun dan dimanapun selama dia terkoneksi dengan sambungan internet.

\section{METODE PENELITIAN}

Metode yang digunakan dalam penelitian ini menggunakan model studi pustaka yaitu metode yang dilakukan dengan mempelajari dan mengumpulkan data dan informasi dari pustaka yang berhubungan dengan materi kajian baik berupa buku maupun sumber informasi lainnya.

Dosen akan melakukan beberapa kegiatan yang terdiri dari beberapa tahap prosedur penelitian yang disajikan pada Gambar 1 sebagai berikut 


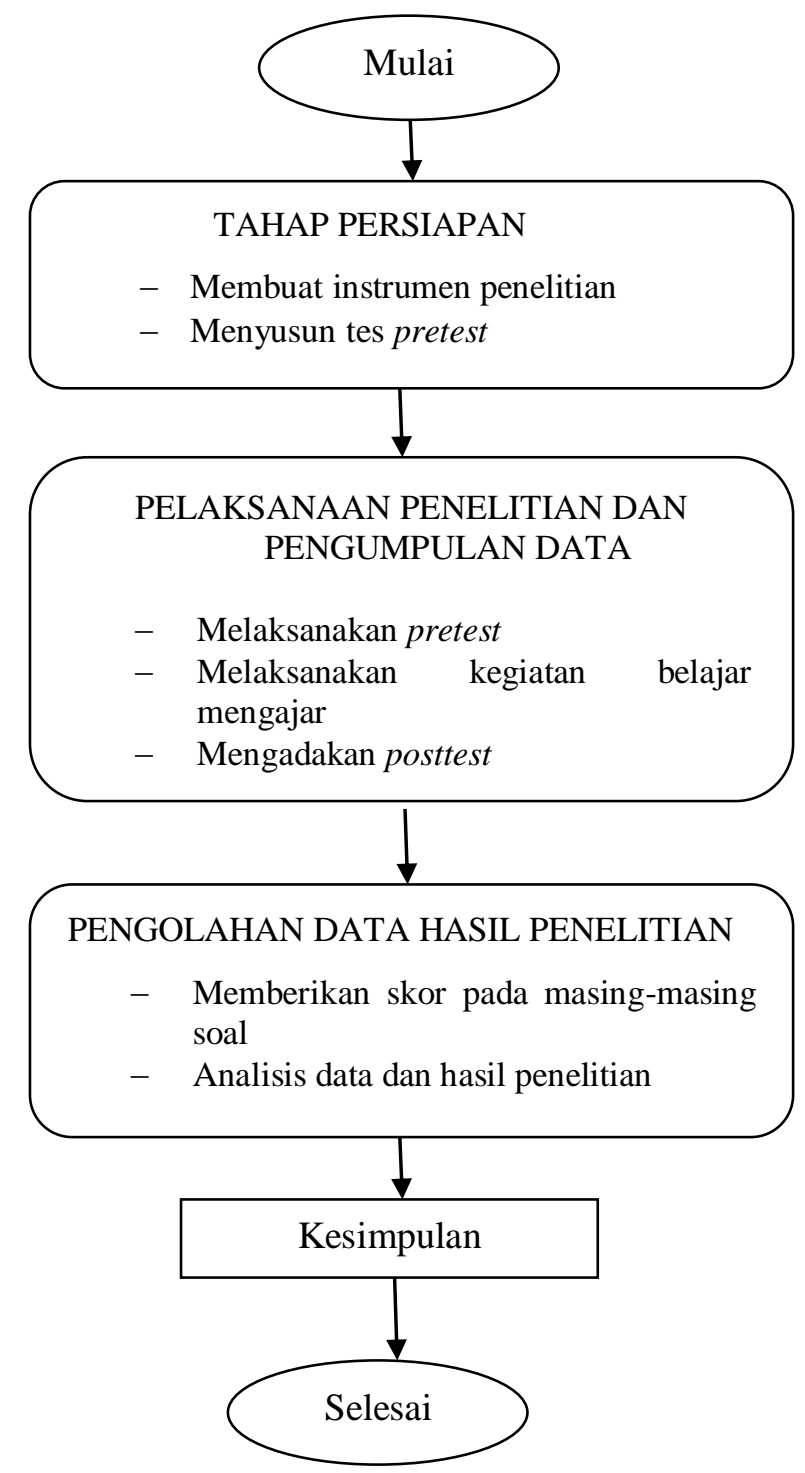

Gambar 1. Diagram Alir Penelitian

Instrumen penelitian adalah alat atau fasilitas yang digunakan peneliti untuk mengumpulkan data agar dalam pekerjaan lebih mudah dan dapat hasil yang akurat dan lebih baik, lengkap dan sistematis sehingga mudah untuk diolah (Arikunto,2002:134).

Instrumen penelitian yang dipergunakan dalam peneliti ini adalah berupa:

a. Pre test atau test tertulis kepada mahasiswa dengan bentuk essay yang disusun sesuai dengan materi yang diajarkan. Instrument ini digunakan untuk mengetahui kemampuan awal siswa dalam ketercapaian proses pembelajaran sebelum dan setelah menggunakan model pembelajaran hybrid.

b. Post test yang bertujuan untuk mengetahui apakah semua materi yang sudah diajarkan dapat dikuasai sebaik-baikya oleh mahasiswa. Materi test yang akan diberikan pada saat post test sama dengan pre test awal.
Validitas dilakukan untuk mengetahui ketepatan dan kelayakan instrumen sebagai alat ukur terhadap konsep atau variabel yang akan diukur, sehingga apa yang seharusnya diukur benar-benar dapat terukur.

Untuk pengujian validitas test si peneliti melakukan uji validitas berdasarkan pendapat para ahli (jugment experts) Sugiyono (2010: 177). Di mana para ahli nanti diminta untuk memberikan keputusan untuk intrument yang akan dilakukan dengan perbaikan atau tidak. Jumlah tenaga ahli (ratter) yang digunakan untuk menguji instrumen soal sebanyak tiga orang pada umumya dengan gelar master sesuai dengan bidang dan lingkup yang akan diteliti. Dosen menguji instrumen dengan para ahli di mana kelas yang akan diteliti hanya satu kelas. Di sini dosen nanti akan menayakan uji instrumen terhadap satu dosen lain yang bersangkutan yang dalam bidang dan ruang lingkup dalam materi daya dukung fondasi dangkal pada Mata Kuliah Teknik Fondasi. Butir instrumen dikatakan valid jika hasil telaah dari tiga ratter/ahli 
paling sedikit dua orang menyatakan bahwa butir soal atau pertayaan tersebut dapat atau layak digunakan.

Sebelum dikonsultasikan dengan ratter tiap-tiap butir instrumen haruslah mengacu pada kriteria-kriteria yang telah dibatasi,yaitu:

1. Rumusan butir instrumen telah sesuai/mengacu dengan indikator atau kisi-kisi instrumen.

2. Bahasa yang digunakan pada tiap butir pertayaan jelas dan dapt dipahami.

3. Rumusan butir instrumen tidak menimbulkan penafsiran ganda yang dapat menyulitkan responden untuk memberikan jawaban.

Menurut Arikunto (2010:208), untuk menghitung validitas instrumen berupa test, menggunakan Indeks Kesukaran (P) dan Daya pembeda (D). Rumus Indeks kesukaran sebagai berikut :

$$
\mathrm{P}=\frac{B}{\text { JS }}
$$

(Pers. 1)

Keterangan:

$$
\begin{aligned}
& \mathrm{P}=\text { Indeks Kesukaran } \\
& \mathrm{B}=\text { Banyak siswa yang menjawab benar } \\
& \mathrm{JS}=\text { Jumlah setiap peserta tes }
\end{aligned}
$$

Dengan kriteria Indeks kesukaran (P).

$0,00 \leq P<0,30$ soal sukar

$0,30 \leq P<0,70$ soal sedang

$0,70 \leq P<1,00$ soal mudah

Sedangkan untuk mengetahui daya pembeda tiap butir soal, menggunakan rumus sebagai berikut :

$$
\mathrm{D}=\frac{B A}{J A}-\frac{B B}{J B}
$$

Keterangan :

$\mathrm{D}$ = Daya pembeda soal

$\mathrm{BA}=$ Banyak siswa kelompok atas yang menjawab benar

$\mathrm{BB}=$ Banyak siswa kelompok bawah yang menjawab benar

$\mathrm{JA}=$ Banyak siswa kelompok atas (27\% dari jumlah seluruh siswa)

$\mathrm{JB}=$ Banyak siswa kelompok bawah (27\% dari jumlah seluruh siswa)

Dengan kriteria daya pembeda (D) sebagai berikut :

$$
\begin{aligned}
& D<0,00 \text { sangat jelek } \\
& 0,00 \leq D<0,20 \text { Jelek } \\
& 0,20 \leq D<0,40 \text { Cukup }
\end{aligned}
$$

\section{Hasil Post-test(Test Akhir)}

Post-test yang diberikan merupakan hasil dari kemampuan peserta didik setelah dilakukanya perlakuan dengan menggunakan model pembelajaran blended learning. Post-test diberikan untuk melihat pengaruh sesudah menggunakan model pembelajaran blended learning yang dilihat dengan berdasarkan pre-

\section{$0,40 \leq \mathrm{D}<0,70$ Baik \\ $0,70 \leq \mathrm{D}<1,00$ Baik sekali}

Pada validitas soal test, soal yang diyatakan valid jika memiliki Indeks Kesukaran yaitu 0,25 $\geq P<0,75$ dan untuk Daya pembeda $D \geq 0,25$. Maka jika salah satu soal kriteria tidak memenuhi,maka soal dinyatakan tidak valid.

\section{Reliabilitas}

Arikunto (2010: 230) mengatakan untuk memperoleh reabilitas instrumen berupa tes digunakan rumus KR-20 sebagai berikut:

$r 11=\left(\frac{k}{k-1}\right)\left(\frac{v t-\Sigma p q}{v t}\right)$

(Pers. 3)

Keterangan :

$r 11=$ Reabilitas instrumen

$P \quad=$ Proporsi mahasiswa yang mendapat angka 1 pada suatu butir

$$
\begin{aligned}
& P \quad=1-P \\
& K=\text { Banyaknya butir yang valid } \\
& V t=\text { Varians total }
\end{aligned}
$$

Kriteria reliabilitas instrumen butir soal sebagai berikut: $r 11 \geq 0,70$ (reliabel) $r 11<0,70$ (tidak reliabel/ un-reliabel)

\section{HASIL DAN PEMBAHASAN} Hasil pre-test (Tes Awal)

Hasil yang diperoleh dari 10 item soal essay, diberikan kepada 26 mahasiswa Prodi Pendidikan Teknik Bangunan Universitas Palangka Raya, dalam pretest ini diberikan untuk langkah awal yang dilakukan peneliti untuk mengukur kemampuan mahasiswa sebelum mengikuti mata kuliah Teknik Fondasi.

Tabel. 2 Data Distribusi Frekuensi Pre-test (Tes Awal).

\begin{tabular}{ccc}
\hline NO & Kelas Interval & Frekuensi \\
\hline 1 & $27-31$ & 2 \\
\hline 2 & $32-36$ & 3 \\
\hline 3 & $37-41$ & 2 \\
\hline 4 & $42-46$ & 6 \\
\hline 5 & $47-51$ & 4 \\
\hline 6 & $52-56$ & 9 \\
\hline & & $\mathbf{N}=\mathbf{2 6}$ \\
\hline
\end{tabular}

test yang sebelumya dilakukan. Selain itu juga post-test merupakan evaluasi untuk melihat ketercapain hasil belajar setelah dilakukaan kegiatan pembelajaran.

Tabel. 3 Data hasil Post-test (tes Akhir)

\begin{tabular}{ccc}
\hline NO & Kelas Interval & Frekuensi \\
\hline 1 & $60-65$ & 2 \\
\hline
\end{tabular}




\begin{tabular}{lcc}
\hline 2 & $66-71$ & 4 \\
\hline 3 & $72-77$ & 8 \\
\hline 4 & $78-83$ & 6 \\
\hline 5 & $84-89$ & 4 \\
\hline 6 & $90-95$ & 2 \\
\hline & & $\mathbf{N}=\mathbf{2 6}$ \\
\hline
\end{tabular}

Sumber: Data Hasil Perhitungan

\section{Pengujian Hipotesis}

\section{Uji Normalitas}

Berdasarkan perhitungan untuk uji normalitas pretest belajar siswa diperoleh harga $\mathrm{X}^{2}$ hitung sebesar 8,5656. Uji normalitas terhadap hasil belajar (post-test) siswa diperoleh harga $\mathrm{X}^{2}$ tabelsebesar 8,6309. Harga-harga tersebut selanjutya di di konfersikan dengan nilai harga $X^{2}$ hitung $<X^{2}$ tabel.Adapun harga di tentukan dengan derajat kebebesan $(\mathbf{d b})=\mathbf{6 - 1}=\mathbf{5}$ adalah 11,070 , jadi hasil dari perhitungan data yang di peroleh berdistribusi normal.

\section{Hasil Belajar}

Dari data-data yang telah dikumpulkan akan diolah untuk menjawab rumusan masalah yang telah disusun yaitu bagaimanakah pengaruh model pembelajaran tipe hybrid learning terhadap hasil belajar siswa pada mata kuliah Teknik Fondasi Prodi Pendidikan Teknik Bangunan FKIP Universitas Palangka Raya. Untuk menjawab rumusan masalah tersebut digunakan perhitungan uji- $t$ untuk mengetahui perbandingan antara dua variabel atau model pembelajara serta dapat mengetahui perbedaan atau tidaknya hasil perhitungan kedua model pembelajaran yang dikonsultasikan terhadap ttabel dan thitung.

Untuk mengetahui hasil perhitungan model one group pre-test post-test design maka peneliti menggunakan rumusan uji $t$ ( $t$-test) untuk pengukuran berulang, karena yang diteliti berpasangan maka data yang diperoleh tersebut di atas dianalisa dengan menggunakan tabel perbandingan pre-test dan posttest.

Tabel 4. Data Perbandingan Nilai Pre-Test dan Post Test ( Sebelum dan Sesudah Menggunakan model pembelajaran hybrid learning).

\begin{tabular}{ccccc}
\hline $\begin{array}{c}\text { No } \\
\text { subjek }\end{array}$ & $\begin{array}{c}\text { Nilai } \\
\text { pre- } \\
\text { test }\end{array}$ & $\begin{array}{c}\text { Nilai } \\
\text { post- } \\
\text { test }\end{array}$ & Selisih(D) & $D^{2}$ \\
\hline 1 & 30 & 75 & 45 & 2025 \\
\hline 2 & 35 & 70 & 35 & 1225 \\
\hline 3 & 40 & 85 & 45 & 2025 \\
\hline 4 & 30 & 60 & 30 & 900 \\
\hline 5 & 40 & 75 & 35 & 1225 \\
\hline 6 & 35 & 80 & 45 & 2025 \\
\hline 7 & 35 & 75 & 40 & 1600 \\
\hline
\end{tabular}

\begin{tabular}{|c|c|c|c|c|}
\hline $\begin{array}{c}\text { No } \\
\text { subjek }\end{array}$ & $\begin{array}{l}\text { Nilai } \\
\text { pre- } \\
\text { test } \\
\end{array}$ & $\begin{array}{c}\text { Nilai } \\
\text { post- } \\
\text { test }\end{array}$ & Selisih(D) & $D^{2}$ \\
\hline 8 & 30 & 65 & 35 & 1225 \\
\hline 9 & 25 & 85 & 60 & 3600 \\
\hline 10 & 20 & 80 & 60 & 3600 \\
\hline 11 & 45 & 95 & 50 & 2500 \\
\hline 12 & 45 & 90 & 45 & 2025 \\
\hline 13 & 30 & 75 & 45 & 2025 \\
\hline 14 & 35 & 70 & 35 & 1225 \\
\hline 15 & 30 & 75 & 45 & 2025 \\
\hline 16 & 30 & 80 & 50 & 2500 \\
\hline 17 & 25 & 80 & 55 & 3025 \\
\hline 18 & 20 & 85 & 65 & 4225 \\
\hline 19 & 30 & 75 & 45 & 2025 \\
\hline 20 & 30 & 70 & 40 & 1600 \\
\hline 21 & 35 & 75 & 40 & 1600 \\
\hline 22 & 35 & 80 & 45 & 2025 \\
\hline 23 & 30 & 75 & 45 & 2025 \\
\hline 24 & 40 & 85 & 45 & 2025 \\
\hline 25 & 40 & 80 & 40 & 1600 \\
\hline 26 & 45 & 70 & 25 & 625 \\
\hline Jumlah & 865 & 2010 & 1145 & 52525 \\
\hline $\begin{array}{c}\text { Rata- } \\
\text { rata }\end{array}$ & 33,2 & 77,3 & 44,0 & 2020,192 \\
\hline
\end{tabular}

Dari data di atas bahwa nilai pre-test pada mata kuliah Teknik Fondasi rata-rata sebesar 33,2 sedangkan posttest nya mempuyai rata-rata sebesar 77,3 .

\section{Pengujian Hipotesis}

Dalam pengujian hipotesis ini digunakan analisi uji $t$ testuntuk mengetahui hasil dari analis apakah signifikan atau tidak. Maka dijelaskanlah $\mathrm{Ha}$ dan Ho sebagai berikut :

$\mathrm{Ha}$ : Terdapat pengaruh model pembelajaran hybrid learning terhadap hasil belajar mahasiswa pada Mata Kuliah Teknik Fondasi Prodi Pendidikan Teknik Bangunan FKIP UPR Tahun Akademik 2020/2021.

Ho : Tidak terdapat pengaruh model pembelajaran hybrid learning terhadap hasil belajar mahasiswa pada Mata Kuliah Teknik Fondasi Prodi Pendidikan Teknik Bangunan FKIP UPR Tahun Akademik 2020/2021.

Uji hipotesis yang dilakukan untuk membuktikan hipotesis diatas maka dari hasil analisis dapat dilihat pada Tabel 5 berikut : 
Tabel 5. Data Hasil Analisis

\begin{tabular}{cccc}
\hline Df & T hitung & $\begin{array}{c}\text { T tabel dengan } \\
\text { kepercayaan } 0,05\end{array}$ & Hasil \\
\hline 25 & 22,4 & 2,06 & t hitung $>$ t tabel
\end{tabular}

\section{(Sumber: tabel daftar $t$ )}

Berdasarkan hasil perhitungan di atas maka di peroleh nilai $t$ sebesar $=24,5$ dimana $\mathrm{df}$ (degree of fredoom) dari data tersebut adalah( $n-1)$, sehingga untuk perhitungan ini d.b (derajat kebebebasan), (26 1). Harga kritisya pada tingkat kepercayaan $5 \%$ adalah 2,06 . Maka dari $t$ hitung dan $t$ tabel dapat disimpulkan bahwa $t$ hitung $>t$ tabel yang berarti

"Terdapat pengaruh model pembelajaran hybrid learning terhadap hasil belajar mahasiswa pada Mata Kuliah Teknik Fondasi Prodi Pendidikan Teknik Bangunan FKIP UPR Tahun Akademik 2020/2021" dan hipotesis Ho ditolak.

Pengujian hipotesis dapat digambarkan dengan kurva sebagai berikut

\begin{tabular}{|c|c|c|c|c|c|}
\hline \multirow[t]{5}{*}{ berikut } & \multirow{5}{*}{$\begin{array}{l}\text { Daerah } \\
\text { Penerimaan } \\
\text { H'o }\end{array}$} & \multirow{2}{*}{2} & \multirow{2}{*}{$\begin{array}{l}\text { Pemakalah } \\
\text { dalam temu } \\
\text { ilmiah }^{2)}\end{array}$} & Nasional & - \\
\hline & & & & Lokal & terdaftar \\
\hline & & 3 & \multicolumn{2}{|l|}{ Bahan ajar ${ }^{3)}$} & tidak ada \\
\hline & & $\begin{array}{l}n \text { Ho } \\
25\end{array}$ & \multicolumn{2}{|c|}{$\begin{array}{l}\text { Luaran lainnya jika ada } \\
\text { (Teknologi Tepat Guna, } \\
\text { Model/Purwarupa/Desai } \\
\text { n/Karya Seni/Rekayasa } \\
\text { Sosial) }\end{array}$} & tidak ada \\
\hline & & 5 & \multicolumn{2}{|c|}{$\begin{array}{l}\text { Tingkat Kesiapan } \\
\text { Teknologi }(\text { TKT })^{5)}\end{array}$} & tidak ada \\
\hline
\end{tabular}

Gambar 2. Kurva Pengujian Hipotesis
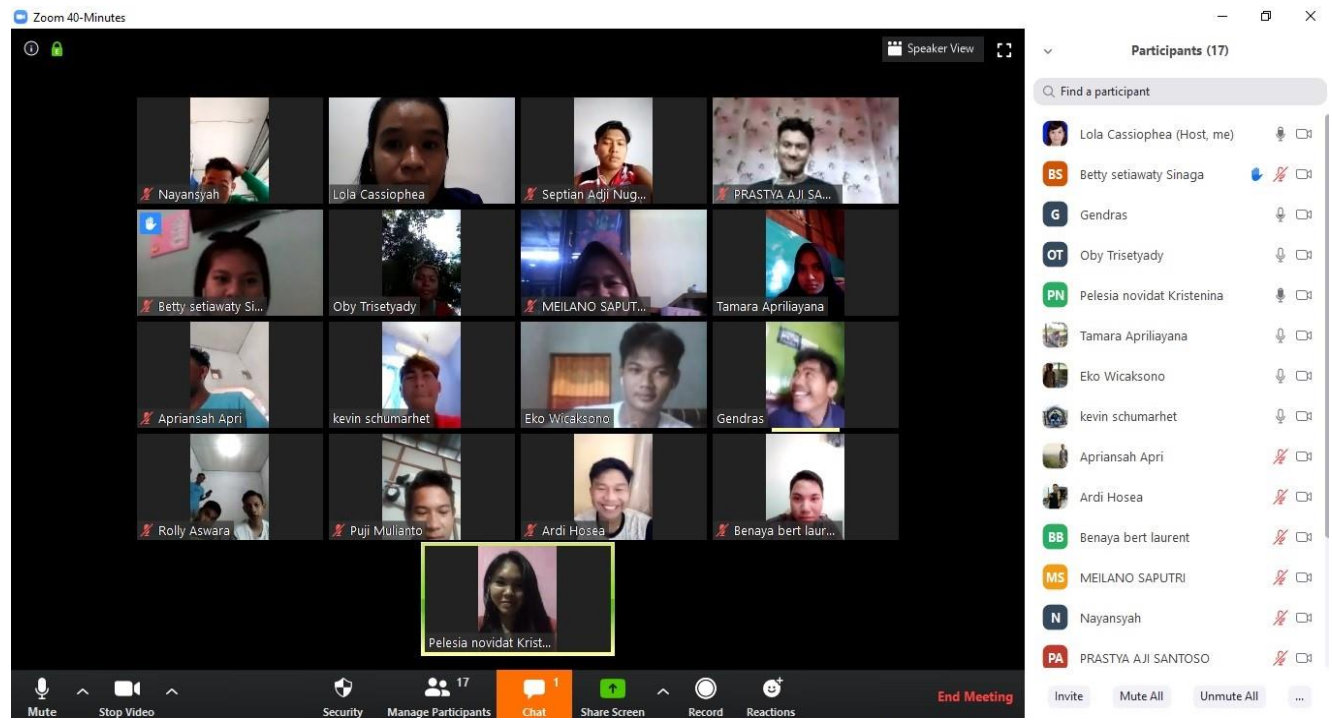

Gambar 3. Dokumentasi Pembelajaran Hybrid Learning dengan zoom meeting 


\section{KESIMPULAN DAN SARAN}

\section{Kesimpulan}

Sesuai dengan hasil penelitian dan analisis yang sudah diuraikan maka dapat ditarik kesimpulan sebagai berikut:

Terdapat pengaruh yang signifikan dibuktikan dengan analisi uji t-test dengan hasil $t_{\text {hitung }}>t_{\text {tabel }}$ dengan nilai thitung $=\mathbf{2 2 , 4}$ sedangkan untuk ttabel= 2,06 dengan kepercayaan $\mathbf{0 , 0 5 \%}$, maka dapat perbedaan yang signifikan pada pembelajaran yang menggunakan model pembelajaran hybrid learning

\section{Saran}

Untuk menyelenggarakan hybrid Leaming terdapat beberapa hal yang perlu diperhatikan antara lain adalah:

1. Penyampaian bahan ajar dan penyampaian pesanpesan yang lain (seperti pengumuman) secara konsisten.

2. Penyelenggaraan pembelajaran melalui hybrid learning harus diselenggarakan secara serius.

3. Bahan ajar yang diberikan harus selalu mengalami perbaikan (update) baik itu formatnya, isinya maupun ketersediaan bahan ajar yang memenuhi kaidah bahan ajar mandiri.

4. Alokasi waktu bisa dimulai dengan formula awal 75:25 dalam artian bahwa 75\% waktu digunakan untuk pembelajaran online dan $25 \%$ waktu digunakan untuk pembelajaran secara tatap muka (konvensional).

\section{DAFTAR PUSTAKA}

Arikunto,Suharsimi(2005). Prosedur Penelitian Suatu Pendekatan Praktik (Edisi Revisi V).Jakarta : PT Asdi Mahasatya, Jakarta.
Arikunto, Suharsimi.(2002). Prosedur Penelitian Suatu Pendekatan Praktik (Edisi Revisi Lima).Jakarta. PT Rineka Cipta.

Arikunto,(2010).Prosedur Penelitian Suatu Pendekatan Praktik (Edisi Revisi vi).Jakarta .PT Rineka Cipta.

Asmawi Zainul, Noehi Nasoetion, MA (2007). Penilain Hasil Belajar .P2T Universitas Terbuka.

Bershin, Josh. (2004). The Blended Beaming Book: Best Bractices, Proven Methodologies, and Lessons Learned. San Francisco: Pfeiffer.

Bonk, C.J., \& Graham, C.R. (2006). The Handbook of Blended Learning Environments: Global Perspectives, Local Designs. SanFransisco: JosseyBass/Pfeiffer

Brunner, D.L. (2006). The Potential of the Hybrid Course Vis-a-Vis Online and Traditional Courses," Teaching Theology and Religion, 9: 4, pp. 229235

Margaret Driscoll, Saul Carliner. Advanced Web-based Training Strategies: Unlocking Instructionality Sound Online learning (San Fransisco:Pfeiffer, 2005)

Margie Martin, 2003, The Hybrid Online Model: Good Practice. Educase quarterly, Number 1.

Nada Dabbagh dan Brenda Bannan, 2005, Online learning Concepts, Strategies, and Application, New Jersey : Pearson Education.

Sugiyono (2009). Metode Penelitian Pendidikan, pendekatan kuantitatif, kualitatif, dan R\&D. Bandung: ALFABETA cv.

Sugiyono (2014). Metod Penelelitian kuantitatif, kualitatif, dan R\&D. Bandung: CV.ALFABETA

Trianto. (2013). Mendesain model pembelajaran inovatif-progresif : Konsep, Landasan, dan Implementasinya pada Kurikulum Tingkat Satuan Pendidikan (KTSP). Jakarta: KENCANA PRENADA MEDIA GROUP. 